\title{
Analysis and summarization of correlations in data cubes and its application in microarray data analysis
}

\author{
Chien-Yu Chen*, Shien-Ching Hwang and Yen-Jen Oyang \\ Department of Computer Science and Information Engineering, National Taiwan University, Taipei, \\ Taiwan, \#1 Roosevelt Rd. Sec. 4, Taipei 106, Taiwan \\ E-mail: \{cychen, schwang\}@mars.csie.ntu.edu.tw; yjoyang@csie.ntu.edu.tw
}

Received 10 December 2003

Revised 7 February 2004

Accepted 5 April 2004

\begin{abstract}
This paper presents a novel mechanism to analyze and summarize the statistical correlations among the attributes of a data cube. To perform the analysis and summarization, this paper proposes a new measure of statistical significance. The main reason for proposing the new measure of statistical significance is to have an essential closure property, which is exploited in the summarization stage of the data mining process. In addition to the closure property, the proposed measure of statistical significance has two other important properties. First, the proposed measure of statistical significance is more conservative than the well-known chi-square test in classical statistics and, therefore, inherits its statistical robustness. This paper does not simply employ the chi-square test due to lack of the desired closure property, which may lead to a precision problem in the summarization process. The second additional property is that, though the proposed measure of statistical significance is more conservative than the chi-square test, for most cases, the proposed measure yields a value that is almost equal to the $\mathrm{z}$ test, a conventional measurement of statistical significance based on the normal distribution. Based on the closure property addressed above, this paper develops an algorithm to summarize the results from performing statistical analysis in the data cube. Though the proposed measure of statistical significance avoids the precision problem due to having the closure property, its conservative nature may lead to a recall rate problem in the data mining process. On the other hand, if the chi-square test, which does not have the closure property, was employed, then the summarization process may suffer a precision problem. In this paper, we also show a possible application in bioinformatics. We applied the proposed mechanism on a microarray dataset, in order to identify groups of genes with similar expression patterns in subspaces of feature space.
\end{abstract}

Keywords: Correlation, data cube, statistical test, segmentation, summarization

\section{Introduction}

Data mining is a process aimed at discovering interesting data patterns hidden in large data sets [8, $12,20]$. Two conventional measures of interestingness or significance of data patterns are "support" and "confidence", which are widely used in mining association rules algorithms [2-5]. However, as addressed in several articles [1,10], "support" and "confidence" are not appropriate in some situations, mainly due

\footnotetext{
${ }^{*}$ Correspondence author: C.-Y. Chen is now with the Graduate School of Biotechnology and Bioinformatics, Yuan Ze University, Chung-Li 320, Taiwan. Tel.: +886 34638800 ext 2185, Fax: +886 3463 8850; E-mail: cychen@ mars.csie.ntu.edu.tw.
} 
to lack of statistical robustness. As a result, a number of alternative measures or tests have been proposed in recent years $[1,6,9,10,13,16-18]$. One of the measures that have been employed recently is the level of significance based on the chi-square test of independence in classical statistics $[6,18]$. The chi-square test is so well known and so widely used that its characteristics has been well studied and its robustness has been well proved.

Brin et al. exploited the chi-square test of independence to find correlation rules in the market basket data set [6]. The same idea has since been exploited in several research works $[9,10,18]$. Nevertheless, previous research works that exploited the chi-square test mainly concerned the market basket data set. One important data model that is widely employed in modern data warehousing and OLAP system is data cube $[7,11,12]$. Therefore, it is of interest to perform correlation analysis in data cubes.

This paper presents a novel mechanism to analyze and summarize the statistical correlation among the attributes of a data cube. Figure 1(a) shows a 2-dimensional data cube example for illustrating the main characteristics of the data mining process. The data set records the network transactions on National Taiwan University Campus during a period of 4 weeks. Figure 1(b) marks the cells in the data cube based on the measure of statistical significance employed in this paper. A cell is marked by "1" ("-1"), if the count in the cell is sufficiently large (small) to exceed a statistical threshold based on the measure of statistical significance.

Based on the primitive statistical analysis, the data mining process proposed in this paper proceeds to summarize the findings of statistical analysis. The summarization process exploits an essential closure property of the measure of statistical significance employed in this paper. The closure property guarantees that if the individual count in each cell of a subcube is statistically significant based on the measure, then the lumped sum of the counts in the subcube must also be statistically significant. The shaded area in Fig. 1(b) shows an example of the summarization process. The summarized result is that all students' dormitories have significantly high network transactions in the evening and midnight.

This paper does not simply employ the chi-square test due to lack of the desired closure property as shown in the 3-D data cube example provided in Fig. 2. This example alone proves that the chi-square test does not have the desired closure property in data cubes.

In this paper, we also show a possible application of the proposed mechanism to microarray data analysis. Wang et.al. proposed that two objects are similar if they exhibit a coherent pattern on a subset of dimensions [19]. In DNA microarray analysis, the expression levels of two genes may rise and fall synchronously in only a subset of environmental conditions. The correlation analysis proposed in this paper is able to identify a set of genes with similar expression patterns in the subspaces of feature space.

In the following part of this paper, Section 2 describes the proposed measure of statistical significance and presents a proof of its closure property. Section 3 elaborates the summarization process. Section 4 discusses the experiments conducted to study the characteristics of the proposed data mining mechanism. Section 5 shows an application of analyzing gene expression profiles. Section 6 presents the concluding remarks of this paper.

\section{The statistical analysis of correlation}

The statistical analysis process employed in this paper borrows some ideas from the chi-square test for independence. In the chi-square test, it is first assumed that the attributes that correspond to different dimensions of the contingency table are completely independent. Then, statistics analysis is applied to determine how likely the outcome of the experiment will distribute as in the contingency table under the 


\begin{tabular}{|c|c|c|c|c|c|}
\hline & $\begin{array}{c}\text { Early } \\
\text { Morning } \\
\text { 3am 7am }\end{array}$ & $\begin{array}{l}\text { Morning } \\
\text { 8am 12pm }\end{array}$ & $\begin{array}{l}\text { Afternoon } \\
1 \mathrm{pm} \sim 5 \mathrm{pm}\end{array}$ & $\begin{array}{c}\text { Evening } \\
6 \mathrm{pm} \sim 9 \mathrm{pm}\end{array}$ & $\begin{array}{l}\text { Midnight } \\
10 \mathrm{pm} 2 \mathrm{am}\end{array}$ \\
\hline $\begin{array}{l}\text { COLLEGE OF ELECTRICAL ENGINEERING AND } \\
\text { COMPUTER SCIENCE }\end{array}$ & 135477 & 673555 & 881915 & 682771 & 421976 \\
\hline COLLEGE OF ENGINEERING & 203370 & 1313483 & 1594946 & 1101980 & 620188 \\
\hline COLLEGE OF SCIENCE & 165602 & 895710 & 1028130 & 663038 & 370613 \\
\hline COLLEGE OF AGRICULTURE & 147298 & 757774 & 868433 & 480345 & 379431 \\
\hline COLLEGE OF MANAGEMENT & 116577 & 269939 & 317198 & 163136 & 105287 \\
\hline COLLEGE OF MEDICINE AND PUBLIC HEALTH & 549810 & 2011089 & 1957590 & 1137670 & 866356 \\
\hline COLLEGE OF LIBERAL ARTS & 12925 & 176390 & 202568 & 63075 & 45442 \\
\hline COLLEGE OF LAW AND SOCIAL SCIENCES & 7083 & 284083 & 351940 & 132700 & 49150 \\
\hline ADMINISTRATION & 1469 & 136128 & 105681 & 41303 & 9620 \\
\hline COMPUTER CENTER & 170553 & 774370 & 1060452 & 555856 & 350399 \\
\hline OTHER CENTERS & 29866 & 444519 & 433194 & 189210 & 58955 \\
\hline LIBRARY & 1960 & 180219 & 161480 & 92509 & 20338 \\
\hline DORMITARY OF GRADUATE STUDENTS & 164117 & 260686 & 333022 & 453445 & 817079 \\
\hline $\begin{array}{l}\text { DORMITARY OF MALE UNDERGRADUATE } \\
\text { STUDENTS }\end{array}$ & 900031 & 1098114 & 1381261 & 1591107 & 2637444 \\
\hline $\begin{array}{l}\text { DORMITARY OF FEMALE UNDERGRADUATE } \\
\text { STUDENTS }\end{array}$ & 193472 & 382212 & 547290 & 685176 & 1049192 \\
\hline
\end{tabular}

(a) A 2-D data cube example.

\begin{tabular}{|c|c|c|c|c|c|}
\hline & \begin{tabular}{|c} 
Early Morning \\
3am 7am
\end{tabular} & $\begin{array}{c}\text { Morning } \\
8 \mathrm{am} \sim 12 \mathrm{pm}\end{array}$ & $\begin{array}{l}\text { Afternoon } \\
1 \mathrm{pm} \sim 5 \mathrm{pm}\end{array}$ & \begin{tabular}{|c|} 
Evening \\
$6 \mathrm{pm} \sim 9 \mathrm{pm}$ \\
\end{tabular} & $\begin{array}{c}\text { Midnight } \\
10 \mathrm{pm} \sim 2 \mathrm{am}\end{array}$ \\
\hline $\begin{array}{l}\text { COLLEGE OF ELECTRICAL ENGINEERING AND } \\
\text { COMPUTER SCIENCE }\end{array}$ & -1 & -1 & 1 & 1 & -1 \\
\hline COLLEGE OF ENGINEERING & -1 & 1 & 1 & 1 & -1 \\
\hline COLLEGE OF SCIENCE & -1 & 1 & 1 & 1 & -1 \\
\hline COLLEGE OF AGRICULTURE & -1 & 1 & 1 & -1 & -1 \\
\hline COLLEGE OF MANAGEMENT & 1 & 1 & 1 & -1 & -1 \\
\hline COLLEGE OF MEDICINE AND PUBLIC HEALTH & 1 & 1 & 1 & -1 & -1 \\
\hline \begin{tabular}{|l} 
COLLEGE OF LIBERAL ARTS \\
\end{tabular} & -1 & 1 & 1 & -1 & -1 \\
\hline COLLEGE OF LAW AND SOCIAL SCIENCES & -1 & 1 & 1 & -1 & -1 \\
\hline ADMINISTRATION & -1 & 1 & 1 & -1 & -1 \\
\hline COMPUTER CENTER & -1 & 1 & 1 & -1 & -1 \\
\hline OTHER CENTERS & -1 & 1 & 1 & -1 & -1 \\
\hline LIBRARY & -1 & 1 & 1 & 0 & -1 \\
\hline DORMITARY OF GRADUATE STUDENTS & 1 & -1 & -1 & 1 & 1 \\
\hline $\begin{array}{l}\text { DORMITARY OF MALE UNDERGRADUATE } \\
\text { STUDENTS }\end{array}$ & 1 & -1 & -1 & 1 & 1 \\
\hline $\begin{array}{l}\text { DORMITARY OF FEMALE UNDERGRADUATE } \\
\text { STUDENTS }\end{array}$ & -1 & -1 & -1 & 1 & 1 \\
\hline
\end{tabular}

(b) Data cube cells whose counts exceed the threshold of statistical significance.

Fig. 1. A 2-dimensional example for illustrating the main characteristics of the mining process.

assumption of independence. If it is highly unlikely in the statistical sense, then it is said that the initial assumption of independence does not hold, i.e. these attributes are correlated or dependent.

The statistical analysis proposed in this paper also assumes that the attributes that correspond to different dimensions of the data cube are independent. Then, a measure of statistical significance is applied to evaluate the significance of the count in each cell of the data cube under the assumption of independence. Let $A_{1}, A_{2}, \ldots, A_{M}$ denote the $M$ attributes corresponding to different dimension of the data cube, and $N$ denote the total count of objects in the data cube. Assume that attribute $A_{k}$ has $L_{k}$ possible values, indexed by $1,2, \ldots, \mathrm{L}_{k}$ and all the attributes are uncorrelated or independent. Figure 3 shows an example of a 3-dimensional data cube.

For each cell in the data cube, we can define a binomial random variable [14] corresponding to the 


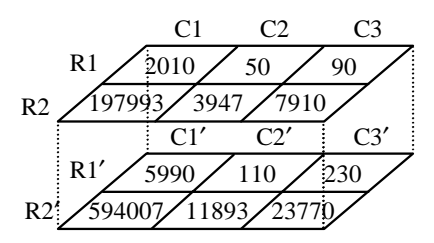

The chi-square statistic for the cell indexed by $\mathrm{R} 1$ and $\mathrm{C} 1$ is

$$
\begin{aligned}
& (2010-2000)^{2} / 2000+(140-120)^{2} / 120+(197993-198000)^{2} / 198000+(11857-11880)^{2} / 11880 \\
& +(5990-6000)^{2} / 6000+(340-360)^{2} / 360+(594007-594000)^{2} / 594000+(35663-35640)^{2} / 35640 \\
& =4.571>2.706
\end{aligned}
$$

, where 2.706 is the chi-square critical value used as threshold.

The chi-square statistic for the cell indexed by R1 and C2 is

$$
\begin{aligned}
& (50-40)^{2} / 40+(2100-2080)^{2} / 2080+(3947-3960)^{2} / 3960+(205903-205920)^{2} / 205920 \\
& +(110-120)^{2} / 120+(6220-6240)^{2} / 6240+(11893-11880)^{2} / 11880+(617777-617760)^{2} / 617760 \\
& =3.649>2.706
\end{aligned}
$$

The chi-square statistic for the subcube containing the tw o cells above is

$$
\begin{aligned}
& (2060-2040)^{2} / 2040+(90-80)^{2} / 80+(201940-201960)^{2} / 201960+(7910-7920)^{2} / 7920 \\
& +(6100-6120)^{2} / 6120+(230-240)^{2} / 240+(605900-605880)^{2} / 605880+(23770-23760)^{2} / 23760 \\
& =1.948<2.706
\end{aligned}
$$

Fig. 2. An example demonstrates that the chi-square test does not have the desired closure property in data cubes.

number of objects, out of the total of $N$ objects, that satisfy this particular attribute combination. Let $V\left(k_{1}, k_{2}, \ldots, k_{M}\right)$ denote the random variable that corresponds to the cell indexed by $\left(k_{1}, k_{2}, \ldots, k_{M}\right)$ and $C\left(k_{1}, k_{2}, \ldots, k_{M}\right)$ denote the actual count in the data cube, which is regarded as the experiment outcome. Just like in the chi-square test, the probability that a single object takes attribute combination $\left(A_{1}=k_{1}, A_{2}=k_{2}, \ldots, A_{M}=k_{M}\right)$ is computed by $\Pi_{i=1}^{M} \operatorname{Prob}\left(\boldsymbol{A}_{i}=\boldsymbol{k}_{i}\right)$, where

$$
\operatorname{Prob}\left(\boldsymbol{A}_{i}=\boldsymbol{k}_{i}\right)=\frac{\text { summation of the counts of all the cells with } \boldsymbol{A}_{i}=\boldsymbol{k}_{i}}{\boldsymbol{N} \text { : total count in thedatacube }} .
$$

The expected value and standard deviation of $V\left(k_{1}, k_{2}, \ldots, k_{M}\right)$, denoted by $\mu\left(k_{1}, k_{2}, \ldots, k_{M}\right)$ and $\sigma\left(k_{1}, k_{2}, \ldots, \boldsymbol{k}_{M}\right)$, respectively, are equal to

$$
\mu\left(k_{1}, k_{2}, \ldots, k_{M}\right)=N \cdot \prod_{i=1}^{M} \operatorname{Prob}\left(A_{i}=k_{i}\right) \text { and }
$$




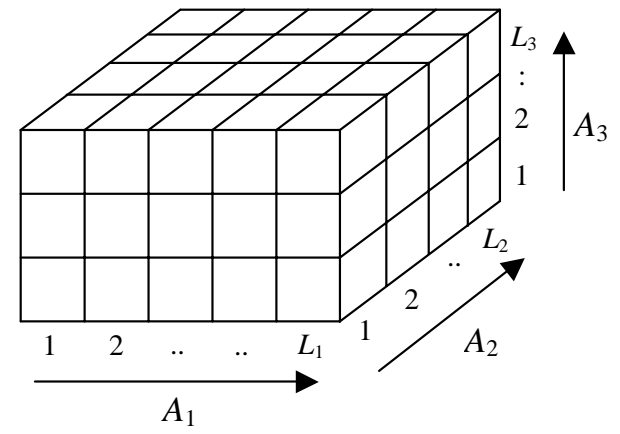

Fig. 3. An example of 3-D data cubes.

$$
\sigma\left(k_{1}, k_{2}, \ldots, k_{M}\right)=\sqrt{N \cdot\left(\prod_{i=1}^{M} \operatorname{Prob}\left(A_{i}=k_{i}\right)\right)\left(1-\prod_{i=1}^{M} \operatorname{Prob}\left(A_{i}=k_{i}\right)\right)} .
$$

The next step is to apply statistics analysis to determine whether the count in each cell is significant in the statistics sense or not. One conventional approach is to apply the $\mathrm{z}$ test [14]. That is, the count at cell indexed by $\left(k_{1}, k_{2}, \ldots, \mathrm{k}_{M}\right)$, i.e, $C\left(k_{1}, k_{2}, \ldots, \mathrm{k}_{M}\right)$, is said to be statistically significant, or attribute combination $\left(A_{1}=k_{1}, A_{2}=k_{2}, \ldots, A_{M}=k_{M}\right)$ is said to be correlated, if

$$
\frac{\left|\frac{C\left(k_{1}, k_{2}, \ldots, k_{M}\right)}{N}-\prod_{i=1}^{M} \operatorname{Prob}\left(A_{i}=k_{i}\right)\right|}{\sqrt{\frac{1}{N} \cdot \prod_{i=1}^{M} \operatorname{Prob}\left(A_{i}=k_{i}\right) \cdot\left(1-\prod_{i=1}^{M} \operatorname{Prob}\left(A_{i}=k_{i}\right)\right)}} \geqslant z_{\alpha / 2}
$$

or

$$
\frac{\left(C\left(k_{1}, k_{2}, \ldots, k_{M}\right)-N \cdot \prod_{i=1}^{M} \operatorname{Prob}\left(A_{i}=k_{i}\right)\right)^{2}}{N \cdot \prod_{i=1}^{M} \operatorname{Prob}\left(A_{i}=k_{i}\right) \cdot\left(1-\prod_{i=1}^{M} \operatorname{Prob}\left(A_{i}=k_{i}\right)\right)} \geqslant z_{\alpha / 2}^{2}
$$

where $z_{\alpha / 2}$ is the threshold of statistical significance for the two-sided $z$ test.

In this paper, in order to have a closure property, we employ a slightly more conservative measure and say that $C\left(k_{1}, k_{2}, \ldots, \mathrm{k}_{M}\right)$ is statistically significant, or attribute value combination $\left(A_{1}=k_{1}, A_{2}=\right.$ $\left.k_{2}, \ldots, A_{M}=k_{M}\right)$ is correlated, if

$$
\begin{aligned}
S\left(k_{1}, k_{2}, \ldots, k_{M}\right)= & \frac{\left[C\left(k_{1}, k_{2}, \ldots, k_{M}\right)-N \cdot \prod_{i=1}^{M} \operatorname{Prob}\left(A_{i}=k_{i}\right)\right]^{2}}{N \cdot \prod_{i=1}^{M} \operatorname{Prob}\left(A_{i}=k_{i}\right)} \\
& =\frac{\left(C\left(k_{1}, k_{2}, \ldots k_{M}\right)-\mu\left(k_{1}, k_{2}, \ldots k_{M}\right)\right)^{2}}{\mu\left(k_{1}, k_{2}, \ldots, k_{M}\right)} \geqslant z_{\alpha / 2}^{2} .
\end{aligned}
$$


The significance measure employed in this paper is more conservative than the conventional $\mathrm{z}$ test, because

$$
N \cdot \prod_{i=1}^{M} \operatorname{Prob}\left(A_{i}=k_{i}\right) \geqslant N \cdot\left(\prod_{i=1}^{M} \operatorname{Prob}\left(A_{i}=k_{i}\right)\right)\left(1-\prod_{i=1}^{M} \operatorname{Prob}\left(A_{i}=k_{i}\right)\right) .
$$

However, the difference is marginal for the applications that this paper concerns, because a data cube typically contains a large number of cells and therefore we generally have $\prod_{i=1}^{M} \operatorname{Prob}\left(A_{i}=k_{i}\right)<<1$.

As a result, in general we have $\sqrt{S\left(k_{1}, k_{2}, \ldots, k_{M}\right)} \cong\left|\frac{C\left(k_{1}, k_{2}, \ldots, k_{M}\right)-\mu\left(k_{1}, k_{2}, \ldots, k_{M}\right)}{\sigma\left(k_{1}, k_{2}, \ldots, k_{M}\right)}\right|$.

The measure of statistic significance employed in this paper has an important closure property, which will be exploited in the summarization process.

Theorem 1. Let $S\left(h_{1}, h_{2}, \ldots, h_{M}\right)$ and $S\left(k_{1}, k_{2}, \ldots, k_{M}\right)$ be the significance measurements of the two cells indexed by $\left(h_{1}, h_{2}, \ldots, h_{M}\right)$ and $\left(k_{1}, k_{2}, \ldots, k_{M}\right)$, respectively. If $S\left(h_{1}, h_{2}, \ldots, h_{M}\right) \geqslant$ $\theta, S\left(k_{1}, k_{2}, \ldots, k_{M}\right) \geqslant \theta, C\left(h_{1}, h_{2}, \ldots, h_{M}\right)>\mu\left(h_{1}, h_{2}, \ldots, h_{M}\right)$, and $C\left(k_{1}, k_{2}, \ldots, k_{M}\right)>$ $\mu\left(k_{1}, k_{2}, \ldots, k_{M}\right)$, then

$$
\frac{\left[\left(C\left(h_{1}, h_{2}, \ldots, h_{M}\right)+C\left(k_{1}, k_{2}, \ldots, k_{M}\right)\right)-\left(\mu\left(h_{1}, h_{2}, \ldots, h_{M}\right)+\mu\left(k_{1}, k_{2}, \ldots, k_{M}\right)\right)\right]^{2}}{\mu\left(h_{1}, h_{2}, \ldots, h_{M}\right)+\mu\left(k_{1}, k_{2}, \ldots, k_{M}\right)} \geqslant \theta .
$$

Similarly, if $S\left(h_{1}, h_{2}, \ldots, h_{M}\right) \geqslant \theta, S\left(k_{1}, k_{2}, \ldots, k_{M}\right) \geqslant \theta, C\left(h_{1}, h_{2}, \ldots, h_{M}\right)<\mu\left(h_{1}, h_{2}, \ldots, h_{M}\right)$, and $C\left(k_{1}, k_{2}, \ldots, k_{M}\right)<\mu\left(k_{1}, k_{2}, \ldots, k_{M}\right)$, then

$$
\frac{\left[\left(C\left(h_{1}, h_{2}, \ldots, h_{M}\right)+C\left(k_{1}, k_{2}, \ldots, k_{M}\right)\right)-\left(\mu\left(h_{1}, h_{2}, \ldots, h_{M}\right)+\mu\left(k_{1}, k_{2}, \ldots, k_{M}\right)\right)\right]^{2}}{\mu\left(h_{1}, h_{2}, \ldots, h_{M}\right)+\mu\left(k_{1}, k_{2}, \ldots, k_{M}\right)} \geqslant \theta .
$$

Proof. We will only prove the first case. The proof of the second case is similar. Since $S\left(h_{1}, h_{2}, \ldots\right.$, $\left.h_{M}\right) \geqslant \theta$ and $S\left(k_{1}, k_{2}, \ldots, k_{M}\right) \geqslant \theta$, we have $\left[C\left(h_{1}, h_{2}, \ldots, h_{M}\right)-\mu\left(h_{1}, h_{2}, \ldots, h_{M}\right)\right]^{2} \geqslant \theta \cdot \mu\left(h_{1}\right.$, $\left.h_{2}, \ldots, h_{M}\right)$ and $\left[C\left(k_{1}, k_{2}, \ldots, k_{M}\right)-\mu\left(k_{1}, k_{2}, \ldots, k_{M}\right)\right]^{2} \geqslant \theta \cdot \mu\left(k_{1}, k_{2}, \ldots, k_{M}\right)$. This implies that

$$
\begin{aligned}
& \frac{\left[\left(C\left(h_{1}, h_{2}, \ldots, h_{M}\right)+C\left(k_{1}, k_{2}, \ldots, k_{M}\right)\right)-\left(\mu\left(h_{1}, h_{2}, \ldots, h_{M}\right)+\mu\left(k_{1}, k_{2}, \ldots, k_{M}\right)\right)\right]^{2}}{\mu\left(h_{1}, h_{2}, \ldots, h_{M}\right)+\mu\left(k_{1}, k_{2}, \ldots, k_{M}\right)} \\
= & \frac{\left[\left(C\left(h_{1}, h_{2}, \ldots, h_{M}\right)-\mu\left(h_{1}, h_{2}, \ldots, h_{M}\right)\right)+\left(C\left(k_{1}, k_{2}, \ldots, k_{M}\right)-\mu\left(k_{1}, k_{2}, \ldots, k_{M}\right)\right)\right]^{2}}{\mu\left(h_{1}, h_{2}, \ldots, h_{M}\right)+\mu\left(k_{1}, k_{2}, \ldots, k_{M}\right)} \\
\geqslant & \frac{\left(C\left(h_{1}, h_{2}, \ldots, h_{M}\right)-\mu\left(h_{1}, h_{2}, \ldots, h_{M}\right)\right)^{2}+\left(C\left(k_{1}, k_{2}, \ldots, k_{M}\right)-\mu\left(k_{1}, k_{2}, \ldots, k_{M}\right)\right)^{2}}{\mu\left(h_{1}, h_{2}, \ldots, h_{M}\right)+\mu\left(k_{1}, k_{2}, \ldots, k_{M}\right)} \\
\geqslant & \frac{\mu\left(h_{1}, h_{2}, \ldots, h_{M}\right) \cdot \theta+\mu\left(k_{1}, k_{2}, \ldots, k_{M}\right) \cdot \theta}{\mu\left(h_{1}, h_{2}, \ldots, h_{M}\right)+\mu\left(k_{1}, k_{2}, \ldots, k_{M}\right)}=\theta .
\end{aligned}
$$

Actually, there are two situations that make $S\left(k_{1}, k_{2}, \ldots, k_{M}\right)$ pass the threshold. One case is $C\left(k_{1}, k_{2}, \ldots, k_{M}\right) \gg \mu\left(k_{1}, k_{2}, \ldots, k_{M}\right)$, which means that the attribute combination $\left(A_{1}=k_{1}, A_{2}=\right.$ $\left.k_{2}, \ldots, A_{M}=k_{M}\right)$ is positively correlated. Another case is $\mu\left(k_{1}, k_{2}, \ldots, k_{M}\right) \gg C\left(k_{1}, k_{2}, \ldots, k_{M}\right)$, which means that the attribute combination $\left(A_{1}=k_{1}, A_{2}=k_{2}, \ldots, A_{M}=k_{M}\right)$ is negatively correlated. Accordingly, we will use a " +1 " to mark a cell that is significant due to the former case, a " -1 " to mark a cell that is significant due to the later case, and a " 0 " to mark a cell that is not significant. Figure 1(b) shows the marked cells for the example given in Fig. 1(a). In Fig. 1(b), the threshold used is $(1.645)^{2}=$ 2.706, where 1.645 is the threshold of the two-sided $\mathrm{z}$ test for 0.1 significance. 


\section{Summarization of the statistical analysis results}

With the cells in the data cube marked according to their significance measurements, the next issue of interest is how to summarize the results from statistics analysis. Theorem 1 implies that if all the cells in a subcube are marked by " +1 "( or " -1 "), then the total count of the subcube also passes the significance criterion. We therefore define the following terms.

Definition 1. A positively(negatively) correlated subcube is a subcube in which all cells are marked by " $+1 "$ ("-1").

Definition 2. A maximum positively (negatively) correlated subcube is a positively (negatively) correlated subcube that is not a subcube of another larger positively (negatively) subcube.

Basically, it is desired to find out all maximum positively correlated subcubes and maximum negatively correlated subcubes. To implement the summarization process, we developed a recursive algorithm based on the conventional algorithm for mining association rules [12]. Let us first use a 3-dimensional data cube to illustrate the basic idea. Assume that it is desired to find all the maximum correlated subcubes of size $l \times m \times n$ or larger in a 3-dimensional data cube as shown in Fig. 3. If we let the $A_{3}$ correspond to the dimension of transactions in the market basket problem, then the problem is transformed to finding all 2-dimensional subcubes of size $l \times m$ or larger on the each of the $A_{1}-A_{2}$ planes defined by different $A_{3}$ values and checking each of such subcubes for having support $n$ or larger on the $A_{3}$ dimension. The task of finding all 2-dimensional subcubes of size $l \times m$ can be carried out by recursively calling the function of finding maximum subcubes. Figure 4 shows the pseudo-code of the recursive algorithm for general multidimensional data cubes. Figure 5 lists all the maximum positively correlated subcubes of size $2 \times 2$ or larger in Fig. 1(b).

\section{Experiments}

This section discusses two experiments conducted to study the characteristics of the correlation analysis and summarization mechanism proposed in this paper. The first experiment is to demonstrate a high dimensional data cube case, since the example used in previous discussion has only two dimensions. The second experiment is to illustrate the so-called recall rate problem of the proposed mechanism due to its conservative nature.

The data set used in the first experiment is a network transaction log collected on the National Taiwan University campus over a period of 4 weeks. Each cell in the data cube records the number of network transactions under a particular attribute combination. The counts in the 3-D data cube are listed in Appendix A. The experiment is to mine the correlations among the three attribute dimensions. Figure 6 lists all the maximum positively correlated subcubes of size $2 \times 2 \times 2$ or larger. In this experiment, the threshold used is 2.706, a chi-square critical value.

In the second experiment, the courses enrollment data Shih Chien University is used. Figure 7(a) shows the 2-dimensional data cube. The horizontal attributes dimension corresponds to the 10 categories of general-background courses offered to undergraduate students, while the vertical attributes dimension corresponds to the departments in the college. Each cell in the data cube records the number of students from a particular department who took a particular category of courses. Figure 7(b) shows the measurements of statistical significance of the cells. In Fig. 7(b), the appended positive sign means that the attribute combination corresponding to the cell is positively correlated and the appended negative 


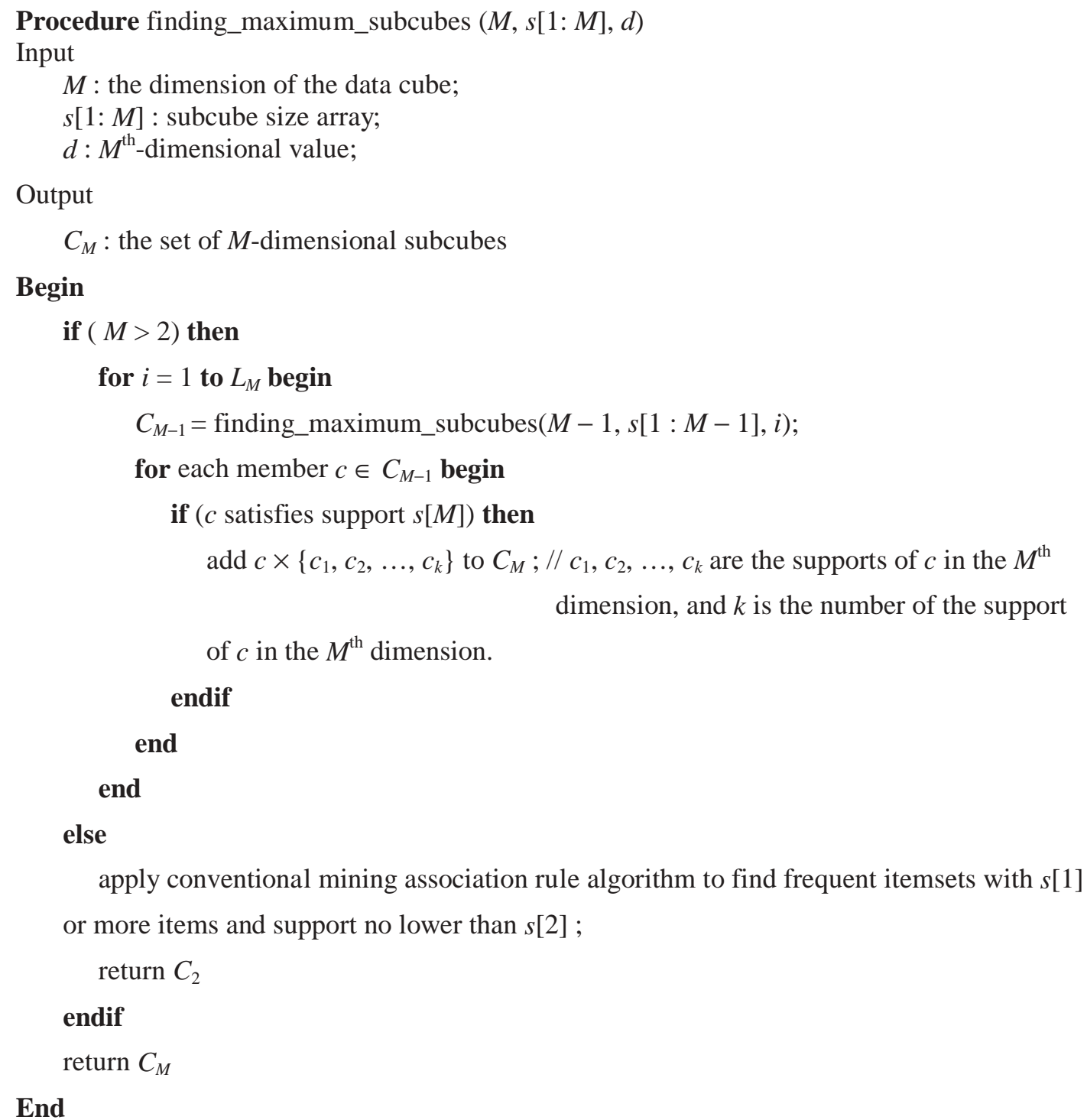

Fig. 4. The pseudo-code for finding maximum correlated subcubes.

sign means that the attribute combination corresponding to the cell is negatively correlated. The so-called recall rate problem occurs at the cell indexed by $\mathrm{R} 4$ and $\mathrm{C} 4$. The value of statistical significance in the cell based on the proposed measure does not exceed 2.076, the chi-square critical value used as threshold. However, as Fig. 7(c) reveals, the chi-square statistic corresponding to the cell does exceed the threshold, i.e. attributes $\mathrm{R} 4$ and $\mathrm{C} 4$ are correlated based on the chi-square test. The reason why the recall rate problem occurs is that the measure of statistical significance proposed in this paper is more conservative than the chi-square statistic. The proposed measure has a nice closure property, but the tradeoff is that it suffers the recall rate problem. On the other hand, if an alternative measure of significance, such as the chi-square test, that does not has the closure property were employed, then the summarization process might faultily include a subcube, in which the lump sum of the counts does not pass the threshold of 


\begin{tabular}{|l|c|c|c|c|c|}
\hline & $\begin{array}{c}\text { C1: } \\
\text { Early Morning } \\
\text { 3am 7am }\end{array}$ & $\begin{array}{c}\text { C2: } \\
\text { Morning } \\
8 \mathrm{am} \sim 12 \mathrm{pm}\end{array}$ & $\begin{array}{c}\text { C3: } \\
\text { Afternoon } \\
\text { 1pm } \sim 5 \mathrm{pm}\end{array}$ & $\begin{array}{c}\text { C4: } \\
\text { Evening } \\
\text { 6pm 9pm }\end{array}$ & $\begin{array}{c}\text { C5: } \\
\text { Midnight } \\
\text { 10pm 2am }\end{array}$ \\
\hline $\begin{array}{l}\text { R1: COLLEGE OF ELECTRICAL ENGINEERING AND } \\
\text { COMPUTER SCIENCE }\end{array}$ & -1 & -1 & 1 & 1 & -1 \\
\hline R2: COLLEGE OF ENGINEERING & -1 & 1 & 1 & 1 & -1 \\
\hline R3: COLLEGE OF SCIENCE & -1 & 1 & 1 & 1 & -1 \\
\hline R4: COLLEGE OF AGRICULTURE & -1 & 1 & 1 & -1 & -1 \\
\hline R5: COLLEGE OF MANAGEMENT & 1 & 1 & 1 & -1 & -1 \\
\hline R6: COLLEGE OF MEDICINE AND PUBLIC HEALTH & 1 & 1 & 1 & -1 & -1 \\
\hline R7: COLLEGE OF LIBERAL ARTS & -1 & 1 & 1 & -1 & -1 \\
\hline R8: COLLEGE OF LAW AND SOCIAL SCIENCES & -1 & 1 & 1 & -1 & -1 \\
\hline R9: ADMINISTRATION & -1 & 1 & 1 & -1 & -1 \\
\hline R10: COMPUTER CENTER & -1 & 1 & 1 & -1 & -1 \\
\hline R11: OTHER CENTERS & -1 & 1 & 1 & -1 & -1 \\
\hline R12: LIBRARY & -1 & 1 & 1 & 0 & -1 \\
\hline R13: DORMITARY OF GRADUATE STUDENTS & 1 & -1 & -1 & 1 & 1 \\
\hline $\begin{array}{l}\text { R14: DORMITARY OF MALE UNDERGRADUATE } \\
\text { STUDENTS }\end{array}$ & 1 & -1 & -1 & 1 & 1 \\
\hline $\begin{array}{l}\text { R15: DORMITARY OF FEMALE UNDERGRADUATE } \\
\text { STUDENTS }\end{array}$ & -1 & -1 & -1 & 1 & 1 \\
\hline
\end{tabular}

\begin{tabular}{|c|l|}
\hline $\begin{array}{c}\text { Dimension } \\
\text { of the } \\
\text { subcubes }\end{array}$ & Maximum positively correlated subcubes \\
\hline $2 \times 3$ & $\begin{array}{l}\{\mathrm{R} 5, \mathrm{R} 6\} \times\{\mathrm{C} 1, \mathrm{C} 2, \mathrm{C} 3\} \\
\{\mathrm{R} 13, \mathrm{R} 14\} \times\{\mathrm{C} 1, \mathrm{C} 4, \mathrm{C} 5\}\end{array}$ \\
\hline $3 \times 2$ & $\begin{array}{l}\{\mathrm{R} 1, \mathrm{R} 2, \mathrm{R} 3\} \times\{\mathrm{C} 3, \mathrm{C} 4\} \\
\{\mathrm{R} 13, \mathrm{R} 14, \mathrm{R} 15\}\{\mathrm{C} 4, \mathrm{C} 5\}\end{array}$ \\
\hline $11 \times 2$ & $\{\mathrm{R} 2, \mathrm{R} 3, \mathrm{R} 4, \mathrm{R} 5, \mathrm{R} 6, \mathrm{R} 7, \mathrm{R} 8, \mathrm{R} 9, \mathrm{R} 10, \mathrm{R} 11, \mathrm{R} 12\} \times\{\mathrm{C} 2, \mathrm{C} 3\}$ \\
\hline
\end{tabular}

Fig. 5. The maximum positively correlated subcubes in the example shown in Fig. 1.

statistical significance. This is a precision problem.

\section{Application}

We applied the proposed correlation analysis to a microarray dataset, HL-60 [15]. HL-60, a human myeloid cancer cell line, can be induced to differentiate into benign noncancerous macrophages. The differentiation of HL-60 can be mediated not only by the cell surface receptors but also by numerous soluble and membraneanchored mediators. HL-60 cells are also induced to differentiate into mature cells by exogenous chemicals such TPA in particular. Therefore, chemical induction of HL-60 cell differentiation into macrophages is a good model to study the roles of genes and proteins in cell differentiation [15]. The biologist who created the dataset selected 1697 genes from the original raw data generated by the microarray experiment. The expression values of these 1697 genes are significantly different when compared to a reference experiment. Each gene is described by a profile, which contains 8 expression values measured at the following time points respectively: $0.5-\mathrm{hr}, 1-\mathrm{hr}, 3-\mathrm{hr}, 6-\mathrm{hr}$, 9-hr, 12-hr, 24-hr, and 48-hr. This dataset can be viewed as a 2-dimensional datacube, on which we are going to analyze the correlation between some genes and some particular time points. Figure 8 shows two subcubes derived by the proposed algorithm. In this experiment, the threshold used is 3.841. In Fig. 8(a), 


\begin{tabular}{|c|l|}
\hline $\begin{array}{l}\text { Dimension of } \\
\text { the subcubes }\end{array}$ & Maximum positively correlated subcubes \\
\hline $2 \times 11 \times 2$ & $\{\mathrm{~A} 6, \mathrm{~A} 7\} \times\{\mathrm{B} 1, \mathrm{~B} 2, \mathrm{~B} 3, \mathrm{~B} 4, \mathrm{~B} 5, \mathrm{~B} 6, \mathrm{~B} 7, \mathrm{~B} 8, \mathrm{~B} 9, \mathrm{~B} 10, \mathrm{~B} 11\} \times\{\mathrm{C} 3, \mathrm{C} 4\}$ \\
\hline $4 \times 10 \times 2$ & $\{\mathrm{~A} 4, \mathrm{~A} 5, \mathrm{~A} 6, \mathrm{~A} 7\} \times\{\mathrm{B} 2, \mathrm{~B} 3, \mathrm{~B} 4, \mathrm{~B} 5, \mathrm{~B} 6, \mathrm{~B} 7, \mathrm{~B} 8, \mathrm{~B} 9, \mathrm{~B} 10, \mathrm{~B} 11\} \times\{\mathrm{C} 3, \mathrm{C} 4\}$ \\
\hline $5 \times 8 \times 2$ & $\{\mathrm{~A} 3, \mathrm{~A} 4, \mathrm{~A} 5, \mathrm{~A} 6, \mathrm{~A} 7\} \times\{\mathrm{B} 2, \mathrm{~B} 3, \mathrm{~B} 4, \mathrm{~B} 5, \mathrm{~B} 7, \mathrm{~B} 8, \mathrm{~B} 9, \mathrm{~B} 11\} \times\{\mathrm{C} 3, \mathrm{C} 4\}$ \\
\hline $5 \times 3 \times 2$ & $\{\mathrm{~A} 1, \mathrm{~A} 4, \mathrm{~A} 5, \mathrm{~A} 6, \mathrm{~A} 7\} \times\{\mathrm{B} 3, \mathrm{~B} 4, \mathrm{~B} 6\} \times\{\mathrm{C} 3, \mathrm{C} 4\},\{\mathrm{A} 1, \mathrm{~A} 3, \mathrm{~A} 4, \mathrm{~A} 6, \mathrm{~A} 7\} \times\{\mathrm{B} 3, \mathrm{~B} 4, \mathrm{~B} 12\} \times\{\mathrm{C} 3, \mathrm{C} 4\}$ \\
\hline $3 \times 3 \times 2$ & $\{\mathrm{~A} 3, \mathrm{~A} 4, \mathrm{~A} 5\} \times\{\mathrm{B} 13, \mathrm{~B} 14, \mathrm{~B} 15\} \times\{\mathrm{C} 1, \mathrm{C} 5\}$ \\
\hline $2 \times 3 \times 2$ & $\{\mathrm{~A} 1, \mathrm{~A} 4\} \times\{\mathrm{B} 4, \mathrm{~B} 5, \mathrm{~B} 6\} \times\{\mathrm{C} 2, \mathrm{C} 3\},\{\mathrm{A} 3, \mathrm{~A} 7\} \times\{\mathrm{B} 2, \mathrm{~B} 5, \mathrm{~B} 6\} \times\{\mathrm{C} 2, \mathrm{C} 3\}$ \\
\hline $6 \times 2 \times 2$ & $\{\mathrm{~A} 1, \mathrm{~A} 2, \mathrm{~A} 3, \mathrm{~A} 4, \mathrm{~A} 5, \mathrm{~A} 6\} \times\{\mathrm{B} 5, \mathrm{~B} 6\} \times\{\mathrm{C} 2, \mathrm{C} 3\},\{\mathrm{A} 1, \mathrm{~A} 3, \mathrm{~A} 4, \mathrm{~A} 5, \mathrm{~A} 6, \mathrm{~A} 7\} \times\{\mathrm{B} 3, \mathrm{~B} 4\} \times\{\mathrm{C} 3, \mathrm{C} 4\}$ \\
\hline $5 \times 2 \times 2$ & $\{\mathrm{~A} 1, \mathrm{~A} 2, \mathrm{~A} 5, \mathrm{~A} 6, \mathrm{~A} 7\} \times\{\mathrm{B} 13, \mathrm{~B} 14\} \times\{\mathrm{C} 1, \mathrm{C} 2\},\{\mathrm{A} 1, \mathrm{~A} 2, \mathrm{~A} 5, \mathrm{~A} 6, \mathrm{~A} 7\} \times\{\mathrm{B} 13, \mathrm{~B} 14\} \times\{\mathrm{C} 1, \mathrm{C} 2\}$ \\
\hline $4 \times 2 \times 2$ & $\begin{array}{l}\{\mathrm{A} 1, \mathrm{~A} 2, \mathrm{~A} 3, \mathrm{~A} 4\} \times\{\mathrm{B} 14, \mathrm{~B} 15\} \times\{\mathrm{C} 1, \mathrm{C} 5\},\{\mathrm{A} 2, \mathrm{~A} 3, \mathrm{~A} 4, \mathrm{~A} 5\} \times\{\mathrm{B} 13, \mathrm{~B} 15\} \times\{\mathrm{C} 1, \mathrm{C} 5\}, \\
\{\mathrm{A} 4, \mathrm{~A} 5, \mathrm{~A} 6, \mathrm{~A} 7\} \times\{\mathrm{B} 5, \mathrm{~B} 6\} \times\{\mathrm{C} 2, \mathrm{C} 4\}\end{array}$ \\
\hline $3 \times 2 \times 2$ & $\begin{array}{l}\{\mathrm{A} 3, \mathrm{~A} 4, \mathrm{~A} 5\} \times\{\mathrm{B} 2, \mathrm{~B} 3\} \times\{\mathrm{C} 3, \mathrm{C} 5\},\{\mathrm{A} 3, \mathrm{~A} 6, \mathrm{~A} 7\} \times\{\mathrm{B} 1, \mathrm{~B} 2\} \times\{\mathrm{C} 3, \mathrm{C} 5\}, \\
\{\mathrm{A} 3, \mathrm{~A} 4, \mathrm{~A} 5\} \times\{\mathrm{B} 2, \mathrm{~B} 3\} \times\{\mathrm{C} 4, \mathrm{C} 5\}\end{array}$ \\
\hline $2 \times 2 \times 2$ & $\{\mathrm{~A} 3, \mathrm{~A} 7\} \times\{\mathrm{B} 2, \mathrm{~B} 10\} \times\{\mathrm{C} 3, \mathrm{C} 5\},\{\mathrm{A} 4, \mathrm{~A} 7\} \times\{\mathrm{B} 2, \mathrm{~B} 10\} \times\{\mathrm{C} 4, \mathrm{C} 5\},\{\mathrm{A} 3, \mathrm{~A} 7\} \times\{\mathrm{B} 1, \mathrm{~B} 2\} \times\{\mathrm{C} 4, \mathrm{C} 5\}$ \\
\hline $4 \times 2 \times 3$ & $\{\mathrm{~A} 4, \mathrm{~A} 5, \mathrm{~A} 6, \mathrm{~A} 7\} \times\{\mathrm{B} 5, \mathrm{~B} 6\} \times\{\mathrm{C} 2, \mathrm{C} 3, \mathrm{C} 4\}$ \\
\hline $3 \times 2 \times 3$ & $\{\mathrm{~A} 3, \mathrm{~A} 4, \mathrm{~A} 5\} \times\{\mathrm{B} 2, \mathrm{~B} 4\} \times\{\mathrm{C} 3, \mathrm{C} 4, \mathrm{C} 5\}$ \\
\hline $2 \times 2 \times 3$ & $\begin{array}{l}\{\mathrm{A} 2, \mathrm{~A} 3\} \times\{\mathrm{B} 13, \mathrm{~B} 14\} \times\{\mathrm{C} 1, \mathrm{C} 2, \mathrm{C} 5\},\{\mathrm{A} 1, \mathrm{~A} 3\} \times\{\mathrm{B} 14, \mathrm{~B} 15\} \times\{\mathrm{C} 1, \mathrm{C} 2, \mathrm{C} 5\},\{\mathrm{A} 1, \mathrm{~A} 4\} \times\{\mathrm{B} 4, \\
\mathrm{B} 6\} \times\{\mathrm{C} 2, \mathrm{C} 3, \mathrm{C} 4\},\{\mathrm{A} 3, \mathrm{~A} 7\} \times\{\mathrm{B} 2, \mathrm{~B} 5\} \times\{\mathrm{C} 2, \mathrm{C} 3, \mathrm{C} 4\}\end{array}$ \\
\hline
\end{tabular}

Fig. 6. Maximum positively correlated subcubes of size larger than $2 \times 2 \times 2$ mined in the first experiment.

four genes are identified as having similar expression pattern at time points, 3-hr and 6-hr, while in Fig. 8(b), six genes are identified as with similar expression pattern at time points, 6-hr and 9-hr. The results of correlation analysis are useful in guiding the biologists to design further experiments, in order to identify significant relationships between interested genes.

\section{Conclusion}

Data cube is a data model that is widely employed in modern data warehousing and OLAP system. Therefore, it is of interest to develop a data mining process for data cubes. This paper presents a mechanism to analyze and summarize the statistical correlations among the attributes of a data cube. To perform the analysis and summarization, this paper employs a new measure of statistical significance. The main reason for proposing the new measure of statistical significance is to have a desired closure property. Based on the closure property, this paper develops an algorithm to summarize the results from performing statistical analysis in the data cube.

Though the proposed measure of statistical significance has a nice closure property, its conservative nature may lead to a recall rate problem. That is, it may happens that the count in a cell of the data cube is significant by the classic $\mathrm{z}$ test, but is classified as insignificant by the proposed measure. However, as elaborated in the paper, for the applications that this paper concerns, the difference between the measure proposed in this paper and the $\mathrm{z}$ test is marginal. On the other hand, if an alternative measure of significance, such as the chi-square test, that does not have the closure property were employed, then the summarization process might faultily include a subcube in which the lumped sum of the counts does not pass the threshold of statistical significance. That is, a precision problem results. 


\begin{tabular}{|l|c|c|c|c|c|c|c|c|c|c|}
\hline & $\begin{array}{c}\text { C1 } \\
\text { Linguistic }\end{array}$ & $\begin{array}{c}\text { C2 } \\
\text { Art }\end{array}$ & $\begin{array}{c}\text { C3 } \\
\text { Literature }\end{array}$ & $\begin{array}{c}\text { C4 } \\
\text { Psychology } \\
\text { and social } \\
\text { studies }\end{array}$ & $\begin{array}{c}\text { C5 } \\
\text { Natural } \\
\text { sciences }\end{array}$ & $\begin{array}{c}\text { C6 } \\
\text { Laws } \\
\text { and } \\
\text { politics }\end{array}$ & $\begin{array}{c}\text { C7 } \\
\text { Educational }\end{array}$ & $\begin{array}{c}\text { C8 } \\
\text { Medical }\end{array}$ & $\begin{array}{c}\text { C9 } \\
\text { Applied } \\
\text { science }\end{array}$ & $\begin{array}{c}\text { C10 } \\
\text { Economy }\end{array}$ \\
\hline $\begin{array}{l}\text { R1:International } \\
\text { Business }\end{array}$ & 176 & 244 & 76 & 361 & 21 & 84 & 51 & 336 & 147 & 284 \\
\hline R2:Accounting & 58 & 198 & 86 & 246 & 31 & 44 & 48 & 360 & 173 & 146 \\
\hline R3:Insurance & 68 & 196 & 91 & 252 & 57 & 116 & 51 & 348 & 134 & 154 \\
\hline $\begin{array}{c}\text { R4:Business } \\
\text { Administration }\end{array}$ & 82 & 181 & 132 & 298 & 64 & 90 & 22 & 236 & 137 & 176 \\
\hline $\begin{array}{c}\text { R5:Applied } \\
\text { Foreign } \\
\text { Language }\end{array}$ & 105 & 238 & 100 & 272 & 14 & 55 & 28 & 195 & 80 & 127 \\
\hline $\begin{array}{c}\text { R6:Information } \\
\text { Management }\end{array}$ & 70 & 103 & 24 & 110 & 37 & 25 & 13 & 149 & 60 & 74 \\
\hline
\end{tabular}

(a) A 2-D data cube.

\begin{tabular}{|c|c|c|c|c|c|c|c|c|c|c|}
\hline & $\begin{array}{c}\mathrm{C} 1 \\
\text { Linguistic }\end{array}$ & $\begin{array}{l}\mathrm{C} 2 \\
\text { Art }\end{array}$ & $\begin{array}{c}\mathrm{C} 3 \\
\text { Literature }\end{array}$ & \begin{tabular}{|c|} 
C4 \\
Psychology \\
and social \\
studies
\end{tabular} & \begin{tabular}{|c|} 
C5 \\
Natural \\
sciences
\end{tabular} & $\begin{array}{c}\text { C6 } \\
\text { Laws } \\
\text { and } \\
\text { politics }\end{array}$ & \begin{tabular}{|c|}
$\mathrm{C} 7$ \\
Educational
\end{tabular} & $\begin{array}{c}\mathrm{C} 8 \\
\text { Medical }\end{array}$ & $\begin{array}{c}\text { C9 } \\
\text { Applied } \\
\text { science }\end{array}$ & $\begin{array}{c}\text { C10 } \\
\text { Economy }\end{array}$ \\
\hline $\begin{array}{c}\mathrm{R} 1: \text { International } \\
\text { Business }\end{array}$ & $\begin{array}{c}20.733 \\
(+)\end{array}$ & $\begin{array}{c}1.047 \\
(-)\end{array}$ & $\begin{array}{c}12.961 \\
(-)\end{array}$ & $\begin{array}{c}0.749 \\
(+)\end{array}$ & $\begin{array}{c}17.138 \\
(-)\end{array}$ & $\begin{array}{c}0.859 \\
(-) \\
\end{array}$ & $\begin{array}{c}0.217 \\
(+)\end{array}$ & $\begin{array}{c}2.311 \\
(-)\end{array}$ & $\begin{array}{c}1.799 \\
(-)\end{array}$ & $\begin{array}{c}22.305 \\
(+)\end{array}$ \\
\hline R2:Accounting & $\begin{array}{c}16.487 \\
(-)\end{array}$ & $\begin{array}{c}0.138 \\
(-)\end{array}$ & $\begin{array}{c}0.114 \\
(-)\end{array}$ & $\begin{array}{c}2.143 \\
(-)\end{array}$ & $\begin{array}{c}1.740 \\
(+)\end{array}$ & $\begin{array}{c}11.327 \\
(-)\end{array}$ & $\begin{array}{c}3.073 \\
(+)\end{array}$ & $\begin{array}{c}20.770 \\
(+)\end{array}$ & $\begin{array}{c}16.023 \\
(+)\end{array}$ & $\begin{array}{c}3.035 \\
(-)\end{array}$ \\
\hline R3:Insurance & $\begin{array}{c}12.256 \\
(-)\end{array}$ & $\begin{array}{c}1.637 \\
(-)\end{array}$ & $\begin{array}{c}0.104 \\
(-)\end{array}$ & $\begin{array}{c}3.865 \\
(-)\end{array}$ & $\begin{array}{c}5.893 \\
(+) \\
\end{array}$ & $\begin{array}{c}20.530 \\
(+) \\
\end{array}$ & $\begin{array}{c}3.443 \\
(+)\end{array}$ & $\begin{array}{c}7.882 \\
(+) \\
\end{array}$ & $\begin{array}{c}0.010 \\
(-)\end{array}$ & $\begin{array}{c}3.231 \\
(-) \\
\end{array}$ \\
\hline $\begin{array}{l}\text { R4:Business } \\
\text { Administration }\end{array}$ & $\begin{array}{c}3.251 \\
(-)\end{array}$ & $\begin{array}{c}3.431 \\
(-)\end{array}$ & $\begin{array}{c}18.719 \\
(+)\end{array}$ & $\begin{array}{c}1.982 \\
(+)\end{array}$ & $\begin{array}{c}14.419 \\
(+) \\
\end{array}$ & $\begin{array}{c}3.496 \\
(+)\end{array}$ & $\begin{array}{c}6.815 \\
(-) \\
\end{array}$ & $\begin{array}{c}\begin{array}{c}10.524 \\
(-)\end{array} \\
\end{array}$ & $\begin{array}{c}0.314 \\
(+)\end{array}$ & $\begin{array}{c}0.107 \\
(+)\end{array}$ \\
\hline $\begin{array}{l}\text { R5:Applied } \\
\text { Foreign } \\
\text { Language } \\
\end{array}$ & $\begin{array}{c}4.478 \\
(+)\end{array}$ & $\begin{array}{c}21.098 \\
(+)\end{array}$ & $\begin{array}{c}6.343 \\
(+)\end{array}$ & $\begin{array}{c}5.835 \\
(+)\end{array}$ & $\begin{array}{c}12.045 \\
(-)\end{array}$ & $\begin{array}{c}1.109 \\
(-)\end{array}$ & $\begin{array}{c}0.650 \\
(-)\end{array}$ & $\begin{array}{c}11.887 \\
(-)\end{array}$ & $\begin{array}{c}9.200 \\
(-)\end{array}$ & $\begin{array}{c}2.784 \\
(-)\end{array}$ \\
\hline $\begin{array}{l}\text { R6:Information } \\
\text { Management }\end{array}$ & $\begin{array}{c}11.503 \\
(+)\end{array}$ & $\begin{array}{c}0.347 \\
(-) \\
\end{array}$ & $\begin{array}{c}8.208 \\
(-) \\
\end{array}$ & $\begin{array}{c}2.843 \\
(-) \\
\end{array}$ & $\begin{array}{c}17.733 \\
(+)\end{array}$ & $\begin{array}{c}2.723 \\
(-) \\
\end{array}$ & $\begin{array}{c}1.322 \\
(-) \\
\end{array}$ & $\begin{array}{c}1.240 \\
(+)\end{array}$ & $\begin{array}{c}0.027 \\
(-) \\
\end{array}$ & $\begin{array}{c}0.538 \\
(-) \\
\end{array}$ \\
\hline
\end{tabular}

(b) The measurements of statistical significance in the second experiment.

\begin{tabular}{|c|c|c|}
\hline & $\mathrm{C} 4$ & $\sim \mathrm{C} 4$ \\
\hline $\mathrm{R} 4$ & 298 & 1120 \\
\hline$\sim \mathrm{R} 4$ & 1241 & 5275 \\
\hline
\end{tabular}

$\chi^{2}=2.891$

(c) The cell at which the recall rate problem occurs.

Fig. 7. An experiment on a 2-dimensional data cube to illustrate the so-called recall rate problem of the proposed mechanism due to its conservative nature.

\section{Acknowledgements}

We would like to thank Dr. Hsueh-Fen Juan and Dr. Hsuan-Cheng Huang for providing the microarray expression dataset, HL-60. In addition, their helpful advices made this study possible. 


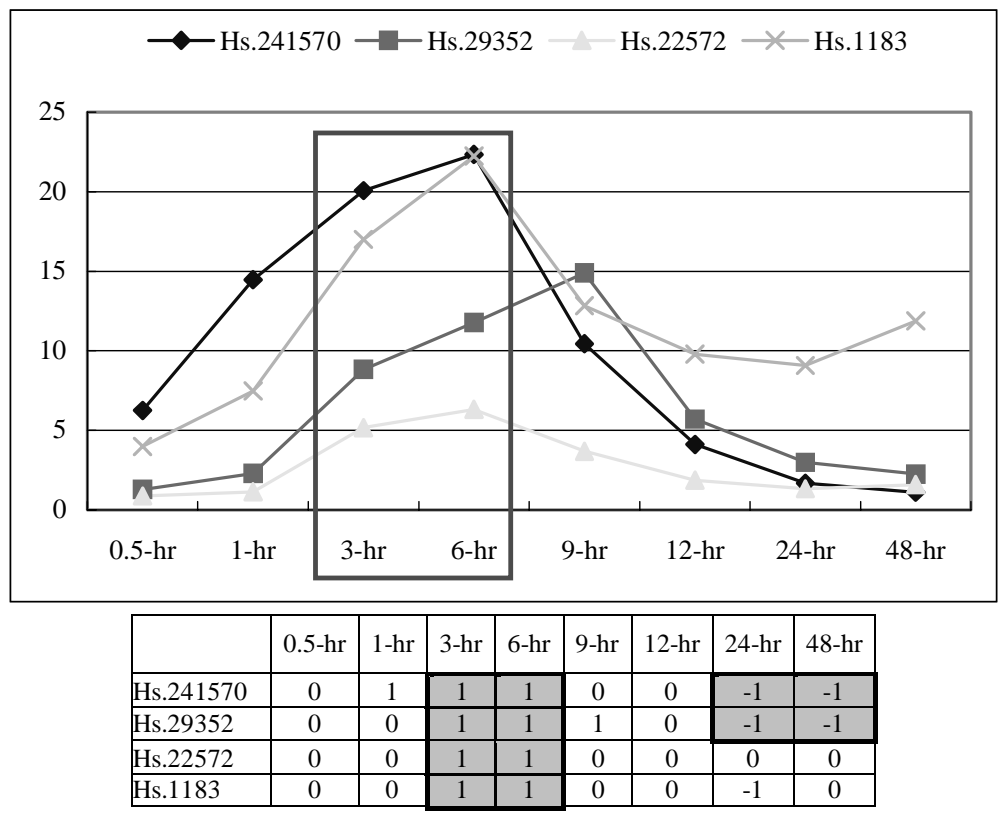

(a) Four genes have similar behaviors at the time points, 3-hr and 6-hr.

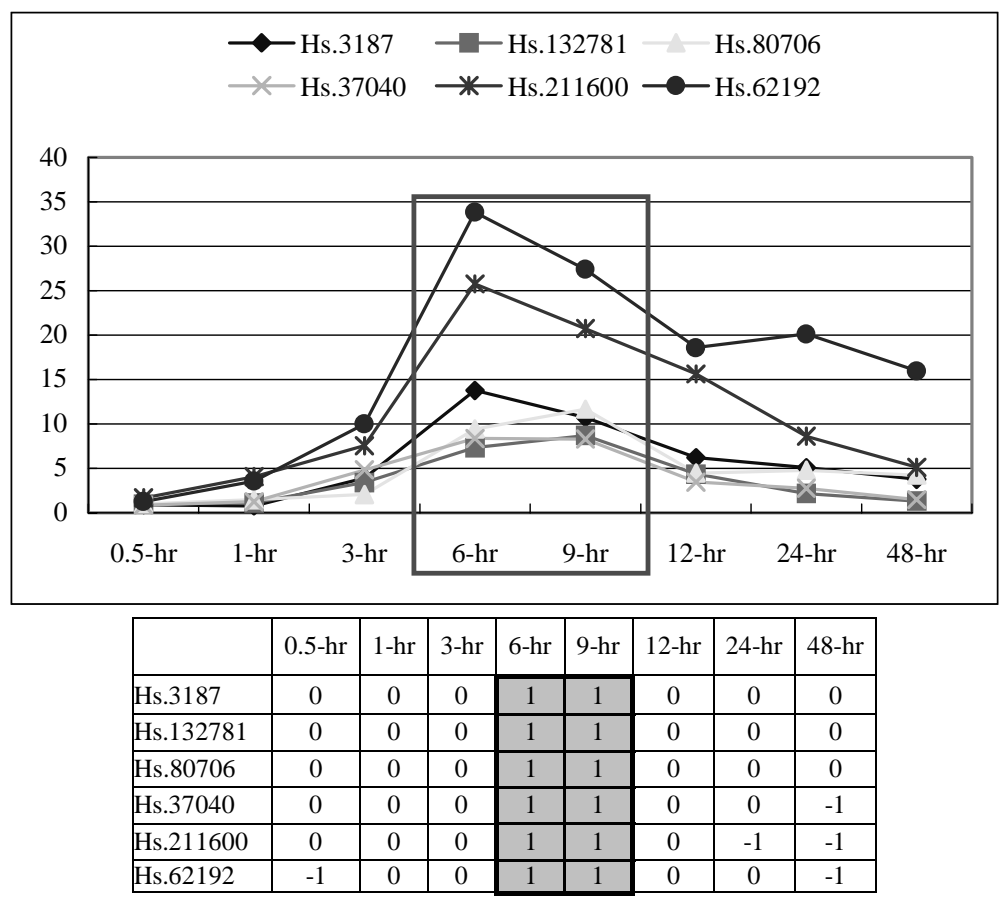

(b) Six genes have similar behaviors at the time points, 6-hr and 9-hr.

Fig. 8. Two subcubes that identify two groups of genes with similar expression behaviors on the specified time points. 


\section{Appendix A}

\begin{tabular}{|c|}
\hline A1: Saturday \\
\hline A2: Sunday \\
\hline A3: Monday \\
\hline A4: Tuesday \\
\hline A5: Wednesday \\
\hline A6: Thursday \\
\hline A7: Friday \\
\hline
\end{tabular}

\begin{tabular}{|l|}
\hline C1: Midnight (10pm 2am) \\
\hline C2: Early morning (3am 7am) \\
\hline C3: Morning (8am 12pm) \\
\hline C4: Afternoon (1pm 5pm) \\
\hline C5: Evening (6pm 9pm) \\
\hline
\end{tabular}

\begin{tabular}{|ll|}
\hline B1: & $\begin{array}{l}\text { COLLEGE OF ELECTRICAL ENGINEERING AND } \\
\text { COMPUTER SCIENCE }\end{array}$ \\
\hline B2: & COLLEGE OF ENGINEERING \\
\hline B3: & COLLEGE OF SCIENCE \\
\hline B4: & COLLEGE OF AGRICULTURE \\
\hline B5: & COLLEGE OF MANAGEMENT \\
\hline B6: & COLLEGE OF MEDICINE AND PUBLIC HEALTH \\
\hline B7: & COLLEGE OF LIBERAL ARTS \\
\hline B8: & COLLEGE OF LAW AND SOCIAL SCIENCES \\
\hline B9: & ADMINISTRATION \\
\hline B10: & COMPUTER CENTER \\
\hline B11: & OTHER CENTERS \\
\hline B12: & LIBRARY \\
\hline B13: & DORMITARY OF GRADUATE STUDENTS \\
\hline B14: & DORMITARY OF MALE UNDERGRADUATE \\
& STUDENTS \\
\hline B15: & DORMITARY OF FEMALE UNDERGRADUATE \\
& STUDENTS \\
\hline
\end{tabular}

(a) Attribute indices of the 3-D data cube

Saturday

\begin{tabular}{|l|r|r|r|r|r|}
\hline & \multicolumn{1}{|c|}{ C1 } & \multicolumn{1}{c|}{ C2 } & \multicolumn{1}{c|}{ C3 } & \multicolumn{1}{c|}{ C4 } & \multicolumn{1}{c|}{ C5 } \\
\hline B1 & 111646 & 11317 & 70782 & 93015 & 51889 \\
\hline B2 & 70703 & 20309 & 154233 & 258454 & 136797 \\
\hline B3 & 33901 & 16065 & 103029 & 120678 & 74350 \\
\hline B4 & 64689 & 36492 & 114657 & 102943 & 47563 \\
\hline B5 & 16412 & 17706 & 36642 & 27491 & 18478 \\
\hline B6 & 119077 & 83742 & 289254 & 251231 & 117701 \\
\hline B7 & 6045 & 308 & 14967 & 14841 & 8554 \\
\hline B8 & 5299 & 69 & 19431 & 21408 & 13268 \\
\hline B9 & 3953 & 270 & 13390 & 4988 & 8005 \\
\hline B10 & 56480 & 32480 & 98298 & 101150 & 39453 \\
\hline B11 & 6165 & 3119 & 52497 & 26601 & 13104 \\
\hline B12 & 5515 & 426 & 34186 & 23649 & 8046 \\
\hline B13 & 118707 & 25011 & 49957 & 65744 & 53263 \\
\hline B14 & 330760 & 155653 & 196951 & 258862 & 219926 \\
\hline B15 & 144538 & 33437 & 65685 & 92015 & 88874 \\
\hline
\end{tabular}

Tuesday

\begin{tabular}{|l|r|r|r|r|r|}
\hline & \multicolumn{1}{c|}{ C1 } & \multicolumn{1}{c|}{ C2 } & \multicolumn{1}{c|}{ C3 } & \multicolumn{1}{c|}{ C4 } & \multicolumn{1}{c|}{ C5 } \\
\hline B1 & 54667 & 30136 & 117193 & 107626 & 82355 \\
\hline B2 & 107460 & 16407 & 205663 & 224036 & 177474 \\
\hline B3 & 45423 & 20307 & 157492 & 157888 & 108729 \\
\hline B4 & 44071 & 35297 & 138452 & 144829 & 78369 \\
\hline B5 & 19124 & 17918 & 45681 & 48264 & 26979 \\
\hline B6 & 126062 & 77123 & 351238 & 325840 & 174630 \\
\hline B7 & 3806 & 1647 & 32649 & 28235 & 13482 \\
\hline B8 & 6644 & 2071 & 47754 & 68570 & 26433 \\
\hline B9 & 48 & 157 & 25076 & 19620 & 7845 \\
\hline B10 & 48502 & 20936 & 123205 & 194752 & 123268 \\
\hline B11 & 11182 & 4135 & 84636 & 80841 & 34058 \\
\hline B12 & 1325 & 481 & 28464 & 21345 & 11410 \\
\hline B13 & 118133 & 17264 & 28654 & 34214 & 79253 \\
\hline B14 & 437777 & 145739 & 166556 & 169407 & 268977 \\
\hline B15 & 172433 & 27627 & 52594 & 70562 & 130340 \\
\hline
\end{tabular}

Sunday

\begin{tabular}{|l|r|r|r|r|r|}
\hline & \multicolumn{1}{|c|}{ C1 } & \multicolumn{1}{c|}{ C2 } & \multicolumn{1}{c|}{ C3 } & \multicolumn{1}{c|}{ C4 } & \multicolumn{1}{c|}{ C5 } \\
\hline B1 & 55773 & 10424 & 49413 & 147849 & 108099 \\
\hline B2 & 102074 & 10713 & 84757 & 195817 & 147368 \\
\hline B3 & 39388 & 13930 & 38407 & 76182 & 59132 \\
\hline B4 & 31796 & 10528 & 43731 & 78532 & 44237 \\
\hline B5 & 14699 & 16817 & 16183 & 24624 & 15853 \\
\hline B6 & 140999 & 73572 & 112946 & 173858 & 157720 \\
\hline B7 & 10895 & 1854 & 6995 & 14451 & 5676 \\
\hline B8 & 7059 & 321 & 11122 & 16744 & 12340 \\
\hline B9 & 4276 & 184 & 3240 & 5482 & 454 \\
\hline B10 & 42710 & 29649 & 60759 & 53901 & 33541 \\
\hline B11 & 6347 & 3887 & 12870 & 20018 & 3844 \\
\hline B12 & 39 & 44 & 5370 & 10166 & 863 \\
\hline B13 & 98811 & 26136 & 39839 & 73985 & 63449 \\
\hline B14 & 355626 & 122935 & 177543 & 294633 & 235663 \\
\hline B15 & 126736 & 21595 & 61789 & 106034 & 97346 \\
\hline
\end{tabular}

Wednesday

\begin{tabular}{|c|c|c|c|c|c|}
\hline & C1 & C2 & C3 & C4 & C5 \\
\hline
\end{tabular} \begin{tabular}{|l|l|l|l|l|l|}
\hline B1 & 47115 & 12906 & 84859 & 97541 & 65657 \\
\hline
\end{tabular} \begin{tabular}{|r|r|r|r|r|r|}
\hline B2 & 73272 & 24768 & 214851 & 238361 & 177878 \\
\hline
\end{tabular} \begin{tabular}{|l|l|l|l|l|l|}
\hline B3 & 85522 & 16597 & 156042 & 148937 & 113768 \\
\hline
\end{tabular} \begin{tabular}{|l|r|r|r|r|r|}
\hline B4 & 69863 & 13758 & 109249 & 121326 & 66084 \\
\hline
\end{tabular} \begin{tabular}{|l|r|r|r|r|r|}
\hline B5 & 16074 & 17456 & 39920 & 46387 & 27687 \\
\hline
\end{tabular} \begin{tabular}{|l|r|r|r|r|r|}
\hline B6 & 122036 & 73242 & 331344 & 291828 & 184212 \\
\hline B7 & 6815 & 1253 & 27408 & 34274 & 12068 \\
\hline
\end{tabular} \begin{tabular}{|l|r|r|r|r|r|}
\hline B7 & 6815 & 1253 & 27408 & 34274 & 12068 \\
\hline B8 & 5368 & 468 & 38572 & 48670 & 19794 \\
\hline
\end{tabular} \begin{tabular}{|l|r|r|r|r|r|}
\hline B8 & 5368 & 468 & 38572 & 48670 & 19794 \\
\hline B9 & 34 & 83 & 23592 & 16771 & 3474 \\
\hline
\end{tabular} \begin{tabular}{|l|r|r|r|r|r|}
\hline B9 & 34 & 83 & 23592 & 16771 & 3474 \\
\hline$B 10$ & 59764 & 29525 & 135980 & 154170 & 81342 \\
\hline
\end{tabular} \begin{tabular}{|r|r|r|r|r|r|}
\hline B10 & 59764 & 29525 & 135980 & 154170 & 81342 \\
\hline B11 & 12743 & 4611 & 67727 & 63384 & 33972 \\
\hline
\end{tabular} \begin{tabular}{|r|r|r|r|r|r|}
\hline B11 & 12743 & 4611 & 67727 & 63384 & 33972 \\
\hline$B 12$ & 1430 & 236 & 17747 & 19132 & 10165 \\
\hline
\end{tabular} \begin{tabular}{|l|r|r|r|r|r|}
\hline B12 & 1430 & 236 & 17747 & 19132 & 10165 \\
\hline B13 & 132963 & 2898 & 45473 & 38517 & 67933 \\
\hline
\end{tabular} \begin{tabular}{|r|r|r|r|r|r|}
\hline B13 & 132963 & 28908 & 45473 & 38517 & 67933 \\
\hline
\end{tabular} \begin{tabular}{|l|l|r|r|r|r|}
\hline B14 & 414513 & 117110 & 141644 & 149411 & 208899 \\
\hline
\end{tabular} \begin{tabular}{|l|l|l|l|l|l|}
\hline B15 & 170582 & 27525 & 51702 & 67620 & 98622 \\
\hline
\end{tabular}
Monday

\begin{tabular}{|l|r|r|r|r|r|}
\hline & \multicolumn{1}{|c|}{ C1 } & \multicolumn{1}{c|}{ C2 } & \multicolumn{1}{c|}{ C3 } & \multicolumn{1}{c|}{ C4 } & \multicolumn{1}{c|}{ C5 } \\
\hline B1 & 40794 & 9906 & 102050 & 109396 & 90006 \\
\hline B2 & 109620 & 61021 & 215304 & 196588 & 151966 \\
\hline B3 & 57276 & 26790 & 124939 & 148371 & 103654 \\
\hline B4 & 41933 & 17255 & 102136 & 123190 & 70326 \\
\hline B5 & 12909 & 16677 & 35027 & 47575 & 21721 \\
\hline B6 & 121665 & 69343 & 273055 & 253318 & 154806 \\
\hline B7 & 3490 & 1026 & 28296 & 35503 & 9300 \\
\hline B8 & 6939 & 3205 & 61119 & 48287 & 21860 \\
\hline B9 & 676 & 216 & 22344 & 20344 & 9817 \\
\hline B10 & 48928 & 15766 & 97225 & 146378 & 82513 \\
\hline B11 & 6566 & 6805 & 67548 & 69070 & 27344 \\
\hline B12 & 414 & 151 & 22115 & 24393 & 11666 \\
\hline B13 & 114816 & 18697 & 31938 & 36553 & 75468 \\
\hline B14 & 401349 & 132539 & 123690 & 149115 & 249349 \\
\hline B15 & 167181 & 40723 & 46102 & 55270 & 96807 \\
\hline
\end{tabular}

Thursday

\begin{tabular}{|l|r|r|r|r|r|}
\hline & \multicolumn{1}{|c|}{ C1 } & \multicolumn{1}{c|}{ C2 } & \multicolumn{1}{c|}{ C3 } & \multicolumn{1}{c|}{ C4 } & \multicolumn{1}{c|}{ C5 } \\
\hline B1 & 37456 & 26618 & 120350 & 150704 & 111170 \\
\hline B2 & 79465 & 17610 & 214848 & 243986 & 151507 \\
\hline B3 & 59018 & 56617 & 169928 & 198325 & 119299 \\
\hline B4 & 64256 & 17840 & 121702 & 149095 & 82544 \\
\hline B5 & 10499 & 17333 & 50298 & 60337 & 23802 \\
\hline B6 & 135178 & 97832 & 348000 & 358920 & 177033 \\
\hline B7 & 6300 & 3257 & 38040 & 39145 & 5830 \\
\hline B8 & 7349 & 686 & 50496 & 94668 & 25066 \\
\hline B9 & 130 & 160 & 25039 & 20723 & 4053 \\
\hline B10 & 42258 & 21911 & 144285 & 216720 & 93097 \\
\hline B11 & 9036 & 3208 & 81745 & 92946 & 37714 \\
\hline B12 & 962 & 450 & 34143 & 31650 & 18454 \\
\hline B13 & 119252 & 23480 & 32472 & 45406 & 60165 \\
\hline B14 & 370648 & 123958 & 156210 & 186306 & 218473 \\
\hline B15 & 143169 & 19766 & 50225 & 84903 & 97416 \\
\hline
\end{tabular}

(b) The 3-D data cube (to be continued). 
Friday

\begin{tabular}{|l|r|r|r|r|r|}
\hline & \multicolumn{1}{|c|}{ C1 } & \multicolumn{1}{c|}{ C2 } & \multicolumn{1}{c|}{ C3 } & \multicolumn{1}{c|}{ C4 } & \multicolumn{1}{c|}{ C5 } \\
\hline B1 & 74525 & 34170 & 128908 & 175784 & 173595 \\
\hline B2 & 77594 & 52542 & 223827 & 237704 & 158990 \\
\hline B3 & 50085 & 15296 & 145873 & 177749 & 84106 \\
\hline B4 & 62823 & 16128 & 127847 & 148518 & 91222 \\
\hline B5 & 15570 & 12670 & 46188 & 62520 & 28616 \\
\hline B6 & 101339 & 74956 & 305252 & 302595 & 171568 \\
\hline B7 & 8091 & 3580 & 28035 & 36119 & 8165 \\
\hline B8 & 10492 & 263 & 55589 & 53593 & 13939 \\
\hline B9 & 503 & 399 & 23447 & 17753 & 7655 \\
\hline B10 & 51757 & 20286 & 114618 & 193381 & 102642 \\
\hline B11 & 6916 & 4101 & 77496 & 80334 & 39174 \\
\hline B12 & 10653 & 172 & 38194 & 31145 & 31905 \\
\hline B13 & 114397 & 24621 & 32353 & 38603 & 53914 \\
\hline B14 & 326771 & 102097 & 135520 & 173527 & 189820 \\
\hline B15 & 124553 & 22799 & 54115 & 70886 & 75771 \\
\hline
\end{tabular}

(b) continues

Saturday
\begin{tabular}{|l|c|c|c|c|c|}
\hline & C1 & C2 & C 3 & C4 & C5 \\
\hline B1 & 1 & 0 & 0 & 0 & 0 \\
\hline B2 & 0 & 0 & 0 & 1 & 1 \\
\hline B3 & 0 & 0 & 1 & 1 & 0 \\
\hline B4 & 0 & 1 & 1 & 1 & 0 \\
\hline B5 & 0 & 1 & 1 & 0 & 0 \\
\hline B6 & 0 & 1 & 1 & 1 & 0 \\
\hline B7 & 0 & 0 & 0 & 0 & 0 \\
\hline B8 & 0 & 0 & 0 & 0 & 0 \\
\hline B9 & 0 & 0 & 1 & 0 & 0 \\
\hline B10 & 0 & 1 & 1 & 0 & 0 \\
\hline B11 & 0 & 0 & 1 & 0 & 0 \\
\hline B12 & 0 & 0 & 1 & 1 & 0 \\
\hline B13 & 1 & 1 & 0 & 0 & 0 \\
\hline B14 & 1 & 1 & 0 & 0 & 1 \\
\hline B15 & 1 & 1 & 0 & 0 & 1 \\
\hline
\end{tabular}

Wednesday

\begin{tabular}{|c|c|c|c|c|c|}
\hline & C1 & C2 & C3 & C4 & C5 \\
\hline B1 & 0 & 0 & 0 & 0 & 0 \\
\hline B2 & 0 & 0 & 1 & 1 & 1 \\
\hline B3 & 0 & 0 & 1 & 1 & 1 \\
\hline B4 & 0 & 0 & 1 & 1 & 0 \\
\hline B5 & 0 & 1 & 1 & 1 & 0 \\
\hline B6 & 0 & 1 & 1 & 1 & 0 \\
\hline B7 & 0 & 0 & 1 & 1 & 0 \\
\hline B8 & 0 & 0 & 1 & 1 & 0 \\
\hline B9 & 0 & 0 & 1 & 1 & 0 \\
\hline B10 & 0 & 0 & 1 & 1 & 0 \\
\hline B11 & 0 & 0 & 1 & 1 & 0 \\
\hline B12 & 0 & 0 & 1 & 0 & 0 \\
\hline B13 & 1 & 1 & 0 & 0 & 1 \\
\hline B14 & 1 & 1 & 0 & 0 & 0 \\
\hline B15 & 1 & 0 & 0 & 0 & 1 \\
\hline
\end{tabular}

Monday

\begin{tabular}{|c|c|c|c|c|c|}
\hline & C1 & C2 & C3 & C4 & C5 \\
\hline B1 & 0 & 0 & 1 & 0 & 1 \\
\hline B2 & 0 & 1 & 1 & 1 & 1 \\
\hline B3 & 0 & 0 & 1 & 1 & 1 \\
\hline B4 & 0 & 0 & 1 & 1 & 0 \\
\hline B5 & 0 & 1 & 1 & 1 & 0 \\
\hline B6 & 0 & 1 & 1 & 0 & 0 \\
\hline B7 & 0 & 0 & 1 & 1 & 0 \\
\hline B8 & 0 & 0 & 1 & 1 & 0 \\
\hline B9 & 0 & 0 & 1 & 1 & 1 \\
\hline B10 & 0 & 0 & 0 & 1 & 0 \\
\hline B11 & 0 & 0 & 1 & 1 & 0 \\
\hline B12 & 0 & 0 & 1 & 1 & 0 \\
\hline B13 & 1 & 0 & 0 & 0 & 1 \\
\hline B14 & 1 & 1 & 0 & 0 & 1 \\
\hline B15 & 1 & 1 & 0 & 0 & 1 \\
\hline
\end{tabular}

Tuesday

\begin{tabular}{|c|c|c|c|c|c|}
\hline & C1 & C2 & C3 & C4 & C5 \\
\hline B1 & 0 & 0 & 1 & 0 & 0 \\
\hline B2 & 0 & 0 & 1 & 1 & 1 \\
\hline B3 & 0 & 0 & 1 & 1 & 1 \\
\hline B4 & 0 & 1 & 1 & 1 & 0 \\
\hline B5 & 0 & 1 & 1 & 1 & 0 \\
\hline B6 & 0 & 1 & 1 & 1 & 0 \\
\hline B7 & 0 & 0 & 1 & 1 & 0 \\
\hline B8 & 0 & 0 & 1 & 1 & 0 \\
\hline B9 & 0 & 0 & 1 & 1 & 0 \\
\hline B10 & 0 & 0 & 1 & 1 & 1 \\
\hline B11 & 0 & 0 & 1 & 1 & 0 \\
\hline B12 & 0 & 0 & 1 & 1 & 0 \\
\hline B13 & 1 & 0 & 0 & 0 & 1 \\
\hline B14 & 1 & 1 & 0 & 0 & 1 \\
\hline B15 & 1 & 0 & 0 & 0 & 1 \\
\hline
\end{tabular}

Friday

Thursday

\begin{tabular}{|c|c|c|c|c|c|}
\hline & C1 & C2 & C3 & C4 & C5 \\
\hline B1 & 0 & 0 & 1 & 1 & 1 \\
\hline B2 & 0 & 0 & 1 & 1 & 0 \\
\hline B3 & 0 & 0 & 1 & 1 & 1 \\
\hline B4 & 0 & 0 & 1 & 1 & 0 \\
\hline B5 & 0 & 1 & 1 & 1 & 0 \\
\hline B6 & 0 & 1 & 1 & 1 & 0 \\
\hline B7 & 0 & 0 & 1 & 1 & 0 \\
\hline B8 & 0 & 0 & 1 & 1 & 0 \\
\hline B9 & 0 & 0 & 1 & 1 & 0 \\
\hline B10 & 0 & 0 & 1 & 1 & 0 \\
\hline B11 & 0 & 0 & 1 & 1 & 0 \\
\hline B12 & 0 & 0 & 1 & 1 & 1 \\
\hline B13 & 1 & 1 & 0 & 0 & 0 \\
\hline B14 & 1 & 1 & 0 & 0 & 0 \\
\hline B15 & 1 & 0 & 0 & 0 & 1 \\
\hline
\end{tabular}

\begin{tabular}{|c|c|c|c|c|c|}
\hline & C1 & C2 & C3 & C4 & C5 \\
\hline B1 & 0 & 1 & 1 & 1 & 1 \\
\hline B2 & 0 & 1 & 1 & 1 & 1 \\
\hline B3 & 0 & 0 & 1 & 1 & 0 \\
\hline B4 & 0 & 0 & 1 & 1 & 1 \\
\hline B5 & 0 & 1 & 1 & 1 & 0 \\
\hline B6 & 0 & 1 & 1 & 1 & 0 \\
\hline B7 & 0 & 0 & 1 & 1 & 0 \\
\hline B8 & 0 & 0 & 1 & 1 & 0 \\
\hline B9 & 0 & 0 & 1 & 1 & 0 \\
\hline B10 & 0 & 0 & 1 & 1 & 1 \\
\hline B11 & 0 & 0 & 1 & 1 & 1 \\
\hline B12 & 0 & 0 & 1 & 1 & 1 \\
\hline B13 & 1 & 1 & 0 & 0 & 0 \\
\hline B14 & 1 & 1 & 0 & 0 & 0 \\
\hline B15 & 1 & 0 & 0 & 0 & 0 \\
\hline
\end{tabular}

(c) Data cube cells that meet statistical significance threshold with positive correlation.

\section{References}

[1] C.C. Aggarwal and P.S. Yu, A new framework for itemset generation, Proceedings of the seventeenth ACM SIGACTSIGMOD-SIGART symposium on Principles of database systems, 1998, pp. 18-24.

[2] R. Agrawal, T. Imielinski and A. Swami, Mining association rules between sets of items in large databases, In Proceedings of ACM SIGMOD Conference on Management of Data (SIGMOD'93), 1993, pp. 207-216. 
[3] R. Agrawal, T. Imielinski and A. Swami, Database mining: A performance prespective, IEEE Transactions on Knowledge and Data Engineering 5 (1993), 914-925.

[4] R. Agrawal, H. Mannila, R. Srikant, H. Toivonen and A.I. Verkamo, Fast Discovery of Association Rules, Advances in Knowledge Discovery and Data Mining, 1996, pp. 307-328.

[5] R. Agrawal and R. Srikant, Fast algorithms for mining association rules in large databases, In 20th Intl Conf. on Very Large Databases (VLDB), Sept. 1994. Expanded version available as IBM Research Report RJ9839, 1994, pp. 487-499.

[6] S. Brin, R. Motwani and C. Silverstein, Beyond market baskets: Generalizing association rules to correlations, In SIGMOD 1997, Proceedings ACM SIGMOD International Conference on Management of Data, 1997, pp. 265-276.

[7] S. Chaudhuri and U. Dayal, An overview of data warehousing and OLAP technology, SIGMOD Record 26 (1997), 65-74.

[8] M.S. Chen, J. Han and P.S. Yu, Data mining: An overview from database perspective, IEEE Transactions on Knowledge and Data Engineering 8 (1996), 866-883.

[9] G. Grahne, L.V.S. Lakshmanan and X. Wang, Interactive Mining of Correlations - A Constraint Perspective, ACM SIGMOD Workshop on Research Issues in Data Mining and Knowledge Discovery (DMKD), 1999.

[10] G. Grahne, L. Lakshmanan and X. Wang, Efficient mining of constrained correlated sets, In Proc. 2000 Int. Conf. Data Engineering (ICDE'00), 2000, pp. 512-521.

[11] J. Gray, A. Bosworth, A. Layman and H. Pirahesh, Data Cube: a relational aggregation operator generalizing group-by, cross-tab, and sub-totals, Proc. of the 12th Intl. Conf. on Data Engineering, 1996, pp. 152-159.

[12] J. Han and M. Kamber, Data mining: concepts and techniques, San Francisco: Morgan Kaufmann Publishers, 2001.

[13] R.J. Hilderman and H.J. Hamilton, Knowledge discovery and interestingness measures: A survey, Technical Report CS 99-04, Department of Computer Science, University of Regina, October, 1999.

[14] R.V. Hogg and E.A. Tanis, Probability and statistical inference, New York: Macmillan, 1988.

[15] H.-F. Juan, J.Y.C. Lin, W.H. Chang, C.Y. Wu, T.L. Pan, M.J. Tseng, K.H. Khoo and S.T. Chen, Biomic study of human myloid leukemia cell (HL-60) differentiated to macrophage using DNA array, proteomic, and bioinformatic analytical methods, Electrophoresis 23 (2002), 2490-2504.

[16] S. Morishita and A. Nakaya, Parallel branch-and-bound graph search for correlated association rules, In Proceedings of ACM SIGKDD Workshop on Large-Scale Parallel KDD Systems, 1999, pp. 127-144.

[17] D. Shah, L.V.S. Lakshmanan, K. Ramamritham and S. Sudarshan, Interestingness and Pruning of Mined Patterns, ACM SIGMOD Workshop on Research Issues in Data Mining and Knowledge Discovery (DMKD), 1999.

[18] C. Silverstein, S. Brin, R. Motwani and J.D. Ullman, Scalable Techniques for Mining Causal Structures, Proceedings of 24th International Conference on Very Large Data Bases, 1998, pp. 594-605.

[19] H. Wang, W. Wang, J. Yang and P.S. Yu, Clustering by pattern similarity in large data sets, In Proceedings of the 2002 ACM SIGMOD International Conference on Management of Data, (SIGMOD-02), 2002, pp. 394-405.

[20] I.H. Witten, Data mining: practical machine learning tools and techniques with Java implementations, San Francisco, California: Morgan Kaufmann, 2000. 